\title{
Analysis of a Blood-Saving Intervention during Blood Collection in Critical Patients
}

\author{
Mònica Maqueda Palau1,2*, Eva Pérez Juan²,3 \\ ${ }^{1}$ Intensive Care Unit, Hospital Universitari Son Espases, Palma de Mallorca, Spain \\ ${ }^{2}$ CurES Research Group, Balearic Islands Health Research Insitute-IdISBa, Palma de Mallorca, Spain \\ ${ }^{3}$ Intensive Care Unit, Hospital de Manacor, Manacor, Spain \\ Email: *momapalau@gmail.com
}

How to cite this paper: Maqueda Palau, M. and Pérez Juan, E. (2021) Analysis of a Blood-Saving Intervention during Blood Collection in Critical Patients. Open Access Library Journal, 8: e7425.

https://doi.org/10.4236/oalib.1107425

Received: April 15, 2021

Accepted: June 4, 2021

Published: June 7, 2021

Copyright ( 2021 by author(s) and Open Access Library Inc.

This work is licensed under the Creative Commons Attribution International License (CC BY 4.0).

http://creativecommons.org/licenses/by/4.0/

\section{(c) (i) Open Access}

\begin{abstract}
Background: To study the impact of 3 blood-saving strategies to reduce the amount of blood collected on the analyses performed on critically ill patients. Methods: Pre-post quasi-experimental study. Population: patients $>18$ years of age, stay of more than 24 hours. Variables: sex, age, diagnosis, admission unit, number of tests performed in 24 hours, volume of waste, usable blood volume, total volume collected in 24 hours, haemoglobin $(\mathrm{Hb})$ at admission and at 24 hours, weight balance, Acute Physiology and Chronic Health Evaluation (APACHE) severity indices, Simplified Acute Physiologic Score (SAPS), catheter, extraction technique, and work experience. A descriptive analysis of variance and association of variables was carried out using the SPSS Statistics 20.0. Results: The average number of laboratory tests per patient 24 hours after admission in the post-intervention phase was $5.8( \pm 1.9)$, compared to $7.2( \pm 2.6)$ in the pre-intervention phase $(\mathrm{p}<0.001)$. The average volume of waste was $14 \mathrm{~mL}( \pm 10.2)$ vs. $31.6 \mathrm{~mL}( \pm 15.8)$ with $\mathrm{p}<0.001$. The average volume of usable blood for the analyses was $22.9 \mathrm{~mL}( \pm 10)$ vs. $48.1 \mathrm{~mL}( \pm 16.7) \mathrm{p}<0.001$. The total volume of usable blood was $38.6 \mathrm{~mL}( \pm 17.6)$ vs. $80.7 \mathrm{~mL}( \pm 26.8) \mathrm{p}<$ 0.001 . Professionals with $<5$ years' experience were found to discard the most blood ( $\mathrm{p}<0.001$ ). Conclusions: The implementation of 3 blood-saving strategies has reduced the volume collected for clinical analysis in critically ill patients by more than $50 \%$ in the first 24 hours of admission.
\end{abstract}

\section{Subject Areas}

Nursing

\section{Keywords}

Phlebotomy, Blood Conservation Strategies, Blood Specimen Collection, Critical Care Nursing, Advanced Practice Nursing 


\section{Background}

Phlebotomy is a routine test performed in hospitals. In critically ill patients, the number of daily collections is usually higher than the standard average, due to the severity of the illnesses causing their admission, resulting in greater blood loss than other patients and the need for blood transfusion [1] [2]. These blood losses can be associated with the pathological process itself, therapeutic support and continuous blood collections for diagnostic purposes, and may contribute to the appearance of hospital-acquired anaemia (HAA) [3]. Severe intra-hospital anaemia occurs in $1.4 \%$ of hospitalised patients and is associated with higher morbidity and mortality [4].

Blood losses related to phlebotomy in Intensive Care Units (ICU) can range between $25 \mathrm{~mL}$ and $377 \mathrm{~mL} /$ day in patients during admission [2] [5] [6]. In previous studies, we carried out a situation analysis in which we examined the blood volume collected from critically ill patients in the first 24 hours of admission, and we concluded that the average blood loss was $80.7 \mathrm{~mL}$ [7] and that the volume of blood collected depended on the number of analytical prescriptions and sampling technique [8]. Routine inpatient laboratory testing reflects wasteful clinical practice that threatens the value of healthcare.

The World Health Organization (WHO) recommends the implementation of programmes that improve clinical practices related to the rational use of allogenic blood products and the implementation of alternatives to blood transfusions [9]. The Patient Blood Management (PBM) programme aims to minimise the risk of transfusion to the patient from a multidisciplinary approach, focused on evidence-based interventions designed to preserve patients' blood volume. They are based on 3 fundamental pillars: comprehensive management of anaemia, optimising the physiological tolerance of the patient's anaemia and minimising iatrogenic blood losses [10].

The evidence-based guideline describes different strategies to reduce blood loss secondary to phlebotomy, some related to the request for laboratory tests: how to rationalise the number of prescriptions and avoid duplicating diagnostic tests [11]. Others are related to reducing the volume of blood for analysis, by using paediatric tubes, or adjusting the amount of blood required in each phlebotomy to the technique to be performed [12] [13] [14]. In ICUs, blood is collected using vascular catheters; some recommendations are aimed at reducing the volume of waste blood through specific systems, or at recording waste volumes [10] [15].

These strategies require a proactive approach, multidisciplinary collaboration, patient-centred care, and adaptation to the local context. The critical care nurse must have resources and protocols that help to minimise iatrogenic blood loss since they are responsible for managing the volume collected in each phlebotomy.

Our theory is that the implementation of these strategies will reduce the blood volume collected from the patient. The objective of this study was to analyse the 
impact of 3 blood-saving strategies implemented to reduce the blood volume collected in analyses performed on critically ill patients.

\section{Methods}

This is a pre-post quasi-experimental study design with a non-equivalent control group.

This study was carried out in the ICU of a tertiary hospital, which has 32 beds in 4 units, including neurotrauma, medical-surgical, coronary and cardiac surgery. Data collection in the pre-intervention phase was from 1 February to April 2017. Implementation phase was carried during 2018, and post-intervention phase, data was collected between 1 February to April 2019.

1) Inclusion criteria: All the patients admitted to any of the ICU units, older than 18 years old, with a stay of at least $24 \mathrm{~h}$. Exclusion criteria: Patients with active bleeding (those who presented detectable or diagnosed blood losses), after cardiac surgery with a blood loss greater than $1.5 \mathrm{~mL} / \mathrm{kg} / \mathrm{h}$ during six consecutive hours within the first $24 \mathrm{~h}$, patients with coagulation pathologies or ones that had received haemoderivatives during the study period.

2) Population and sample: all patients over 18 years of age admitted for 24 hours or more in an ICU were included. Patients with diagnosed blood loss, post-cardiac surgery with blood loss greater than $1.5 \mathrm{~mL} / \mathrm{kg} / \mathrm{h}$ during the first 6 hours after surgery, patients with coagulopathies or those undergoing transfusions during the study period were excluded. Calculation of sample size and selection: the design and calculation of the sample size is based on the assumption that the population standard deviation of the total volume of blood collected on a routine day is $\pm 10 \mathrm{~mL}$. A difference of at least $5 \mathrm{~mL}$ between the pre and post group can be detected by assuming that 100 patients are required in the first group and 100 in the second. An alpha risk of 0.05 and a beta risk of 0.2 have been accepted in a two-sided contrast.

3) Variables. age, sex, medical diagnosis, unit of admission, weight balance at 24 hours, Acute Physiology and Chronic Health Evaluation (APACHE) severity indices, Simplified Acute Physiologic Score (SAPS), number of tests performed in 24 hours, volume of waste blood before specimen collection, usable blood volume for analyses, total blood volume in 24 hours (usable volume for sample analysis plus waste volume) in 24 hours, haemoglobin ( $\mathrm{Hb})$ on admission and at 24 hours, sampling technique, catheter used and work experience.

4) Data collection: The same collection and recording model as in the first phase was used. Annex 1: The forms were completed by the nurses responsible for performing each phlebotomy. The researchers entered data on age, sex, diagnosis, haemoglobin, severity indices, and weight balance.

5) Intervention: After a review of the literature, 3 strategies best adapted to the local context were selected to reduce blood volume:

a) Rationalisation of analytical performance specifications:

i) Adjust each analysis to every patient's needs. 
ii) The troponin collection protocol was modified in the patient with acute myocardial infarction: troponin levels were measured every 4 hours instead of every 2 hours, and it was established that the troponin curve would be suspended when detecting the first decreasing value.

b) Blood volume reduction to analyse:

i) Using smaller volume tubes for clinical analysis (Biochemistry tubes with $8.5 \mathrm{~mL}$ separator gel were replaced by $3.5 \mathrm{~mL}$ ones; $4 \mathrm{~mL}$ lithium heparin biochemistry tubes by $2 \mathrm{~mL}$ ones; $3 \mathrm{~mL}$ EDTA tubes by $2 \mathrm{~mL}$ ones; $2.7 \mathrm{~mL}$ by 1.8 $\mathrm{mL}$ citrate ones). Prior to replacing the tubes, analyses were carried out using higher and lower volumes and the same results were obtained.

ii) Standardisation of the volume collected in blood gas to $1 \mathrm{~mL}$. We use $3 \mathrm{~mL}$ syringes and comparisons of the blood gas results were made with $3 \mathrm{~mL}$ and 1 $\mathrm{mL}$ ones, the results being within the ranges considered optimal by the GEM Premier $4000^{\circ}$ gasometer; the minimum volume required is $0.1 \mathrm{~mL}$ of blood for each analysis.

c) Reduction of the waste volume:

i) Use of the closed system technique to obtain samples through catheters (pressurised systems were used to monitor invasive blood pressure or central venous pressure). A syringe is attached to the patient's distal tap to mix the waste blood with the purging solution. Blood for testing is obtained from the patient's proximal tap. The waste blood is subsequently reintroduced in a sterile manner into the bloodstream.) If this was not possible, the volume of blood collected per catheter used was standardised to twice the volume of the dead space.

ii) Subsequently, a strategy was developed to implement these approaches through information sessions for nurses and doctors, infographics were designed and placed in visible places in the different units of the ICU, an animated video was created explaining the benefits of each strategy, and disseminated through clinical sessions and the mobile network.

d) Data analysis. a descriptive exploratory analysis of the categorical and quantitative variables was performed. Categoric variables were expressed in absolute and relative frequencies. Normally distributed continuous variables were represented by mean and standard deviation and median and interquartile range when normality was not fulfilled. The Kruskall-Wallis variance analysis and the Mann-Whitney $U$ test were used for variables with non-normal distribution and the Student's t-test for those that did meet normality criteria. Associations between variables took place using a Rho de Spearman correlation coefficient. Significant values of $\mathrm{p}<0.05$ were considered. We used the IBM SPSS Statistics 20.0 .

e) Ethical considerations. The study was presented and subsequently approved by the Research Committee of the hospital. No modifications were made to the care or experimental procedures, according to the international standards stipulated in the Helsinki Act (1964). I know guaranteed the confidentiality of the data (Data Confidentiality Law LOPD 15/99). 


\section{Results}

\subsection{Socio-Demographic Data}

During the months of data collection in the post-intervention phase, a total of 574 admissions in ICU, and 130 patients were registered, 18 of which were excluded because they did not meet the inclusion criteria. A sample of 112 patients was used (Figure 1).

A $72.3 \%$ (81) were men, with an average age of $57.8( \pm 17.6)$ and $27.7 \%(31)$ were women, with an average age of $67( \pm 12.4)$. The groups were significantly different in terms of age, sex, diagnosis, unit of admission and SAPS severity index $(p<0.05)$. There was a higher percentage of men in the post-intervention phase. The number of records of post-intervention patients who had undergone cardiac surgery and suffered from subarachnoid haemorrhaging increased with respect to the pre-intervention phase. Table 1 shows details of the variables studied in the pre and post-intervention phases. Variables expressed as median \pm standard deviation, percentages $(\%),{ }^{*}<0.05$.

\subsection{Results of the Number of Samples Collected}

A total of 656 samples were collected, in comparison with 865 in the pre study.

\section{CONSORT Flow Diagram}

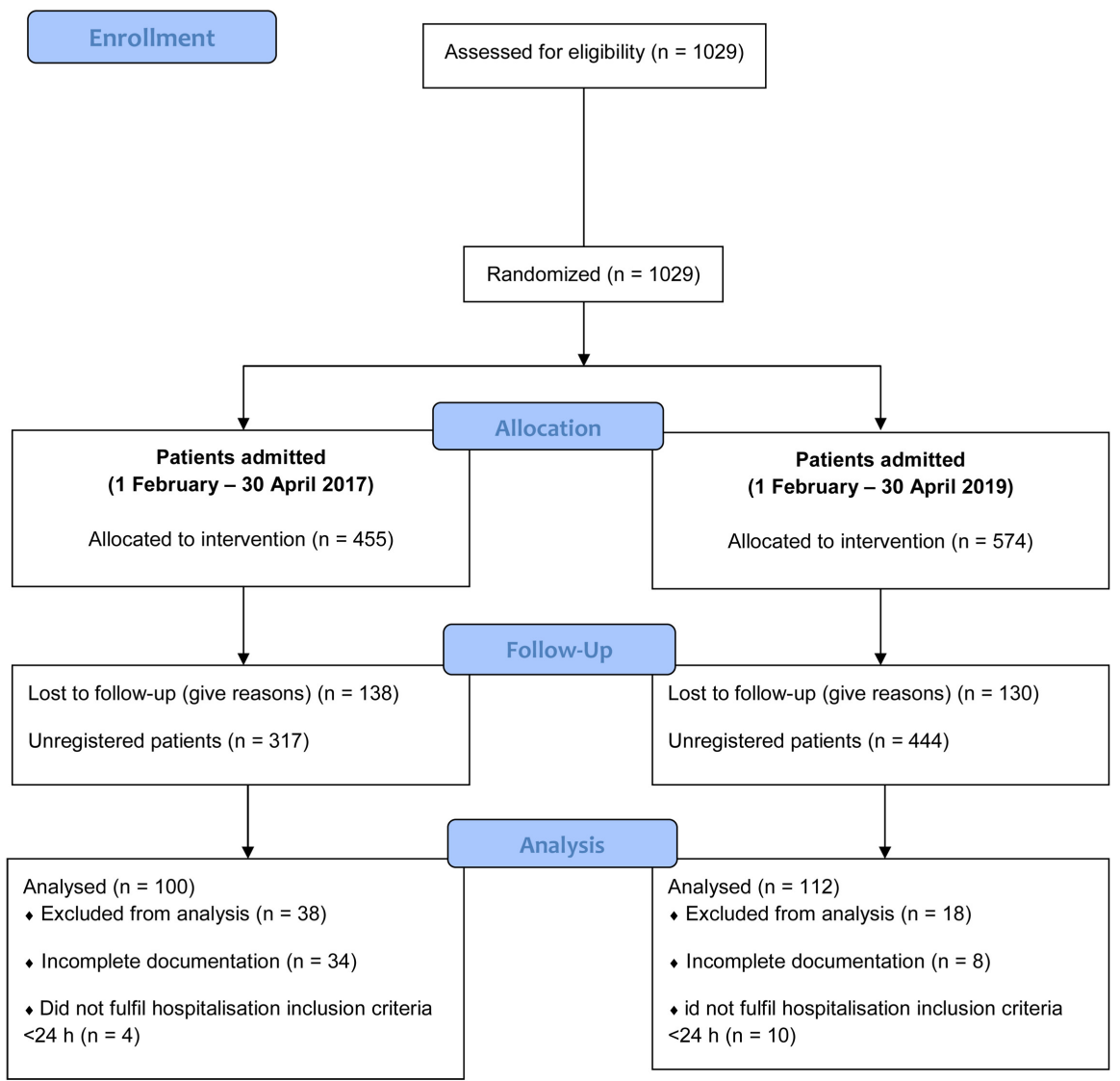

Figure 1. Consort flow diagram. 
Table 1. Variables studied in the pre and post-intervention phases. Subarachnoid haemorrhage (SAH), acute respiratory failure (ARF), post abdominal surgery (Post. Abd). Acute Physiology and Chronic Health Evaluation (APACHE) severity indices, Simplified Acute Physiologic Score (SAPS). ${ }^{*} \mathrm{p}<0.05$.

\begin{tabular}{|c|c|c|c|c|c|}
\hline & \multicolumn{2}{|l|}{ PRE } & \multicolumn{2}{|l|}{ POST } & \multirow{2}{*}{$\begin{array}{r}P \\
0.004^{*}\end{array}$} \\
\hline Age (years) & $\bar{X} 63.7( \pm 13.6)$ & & $\bar{X} 60.3( \pm 16)$ & & \\
\hline \multirow{2}{*}{ Sex } & $42 \%$ Women & & $27.7 \%$ Women & & \multirow{2}{*}{$0.031^{\times}$} \\
\hline & $58 \%$ Men & & $72.3 \%$ Men & & \\
\hline \multirow{7}{*}{$\begin{array}{l}\text { Admission } \\
\text { diagnosis }\end{array}$} & Heart failure & 49 & Heart failure & 29 & \multirow{7}{*}{$0.001^{\times}$} \\
\hline & Heart surgery & 18 & Heart surgery & 42 & \\
\hline & Head injury & 7 & Head injury & 7 & \\
\hline & $\mathrm{SAH}$ & 6 & $\mathrm{SAH}$ & 19 & \\
\hline & $\mathrm{ARF}$ & 5 & $\mathrm{ARF}$ & 6 & \\
\hline & Post.Abc & 5 & Post.Abc & 5 & \\
\hline & Sepctic shock & 5 & Sepctic shock & 4 & \\
\hline \multirow{4}{*}{$\begin{array}{l}\text { Registered patients } \\
\text { according to unit }\end{array}$} & Heart surgery Unit & 18 & Heart surgery Unit & 38 & \multirow{4}{*}{$0.008^{*}$} \\
\hline & Coronary Unit & 49 & Coronary Unit Medical & 50 & \\
\hline & Medical surgery Unit & 20 & surgery Unit & 6 & \\
\hline & Neurocritical Unit & 13 & Neurocritical Unit & 18 & \\
\hline Balance $(\mathrm{mL})$ & $\bar{X} 521.81( \pm 1410)$ & & $\bar{X} 627.32( \pm 1702)$ & & 0.187 \\
\hline \multirow{2}{*}{ Severity index } & \multicolumn{2}{|l|}{ APACHE $\quad \bar{X} 18.7( \pm 9)$} & \multicolumn{2}{|l|}{ APACHE $\quad \bar{X} 19.8( \pm 7.7)$} & 0.128 \\
\hline & \multicolumn{2}{|l|}{ SAPS $\bar{X} 34.8( \pm 13)$} & \multicolumn{2}{|l|}{ SAPS $\bar{X} 38( \pm 15.3)$} & $0.036^{*}$ \\
\hline Sample size & $\mathrm{N}: 100$ & & $\mathrm{~N}: 112$ & & \\
\hline
\end{tabular}

The average number of laboratory tests per patient 24 hours after admission in the post-intervention phase was $5.8( \pm 1.9)$, compared to $7.2( \pm 2.6)$ in the preintervention phase $(\mathrm{p}<0.001)$. A comparison of the number of analyses performed per pathology causing admission shows a reduction in the post phase (Figure 2).

\subsection{Results of the Volume of Blood Collected}

The average volume of waste in $24 \mathrm{~h}$ was $14 \mathrm{~mL}( \pm 10.2)$ in the post phase vs. 31.6 $\mathrm{mL}( \pm 15.8)$ in the pre phase, with $\mathrm{p}<0.001$. The average volume of usable blood for the analyses was $22.9 \mathrm{~mL}( \pm 10)$ in the post phase vs. $48.1 \mathrm{~mL}( \pm 16.7)$ in the pre phase, $\mathrm{p}<0.001$. The total average volume of usable blood in the post phase was $38.6 \mathrm{~mL}( \pm 17.6)$ vs. $80.7 \mathrm{~mL}( \pm 26.8)$ in the pre phase, $\mathrm{p}<0.001$. A decrease in blood volumes was registered in the post phase of: $55.69 \%$ blood waste, $52.39 \%$ usable blood and $52.16 \%$ total volume (Figure 3 ).

A greater number of laboratory tests and blood volume collected from patients after cardiac surgery, acute myocardial infarction (AMI), cardiorespiratory arrest (CRA) and septic shock were recorded compared to patients diagnosed with acute respiratory failure (ARF), polytrauma, head trauma (head injury) and abdominal surgery (Table 2). 


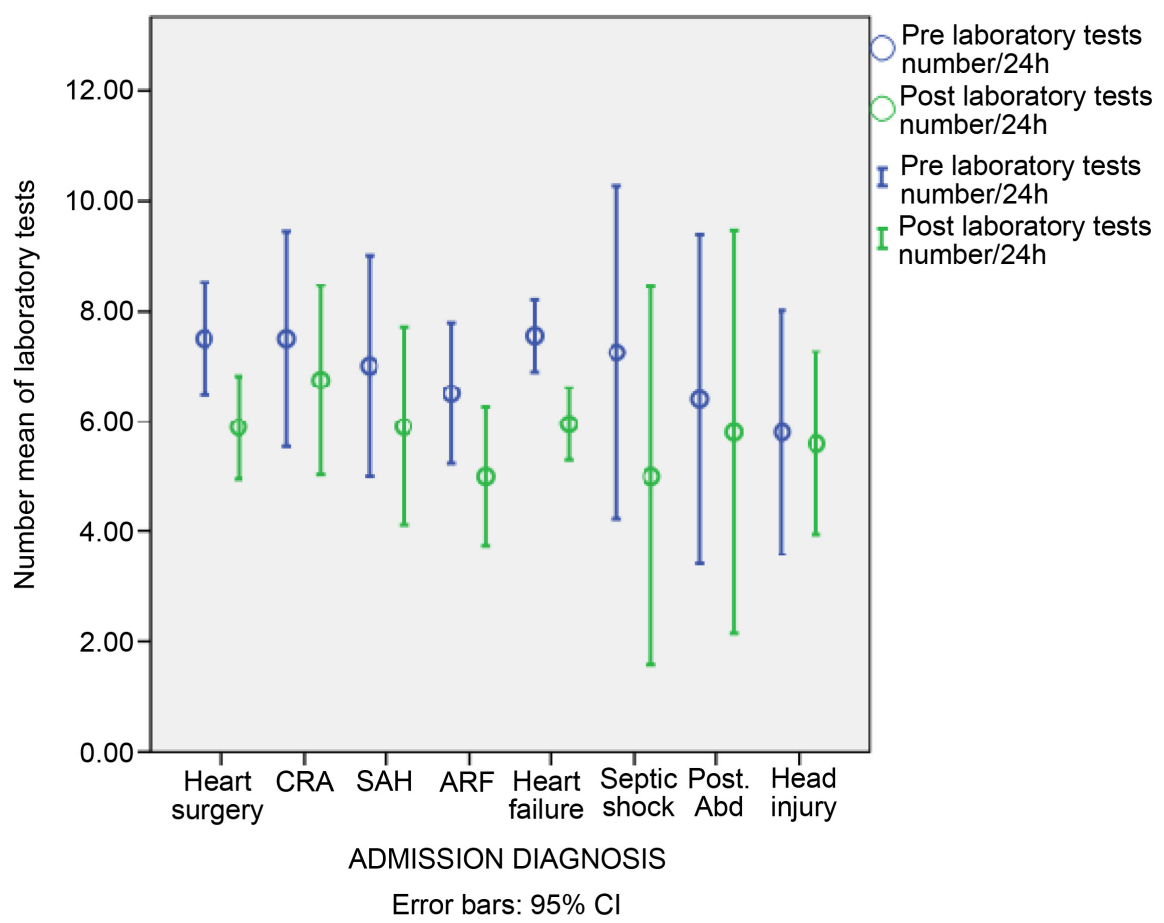

Figure 2. Number of analyses according to pathology causing admission.

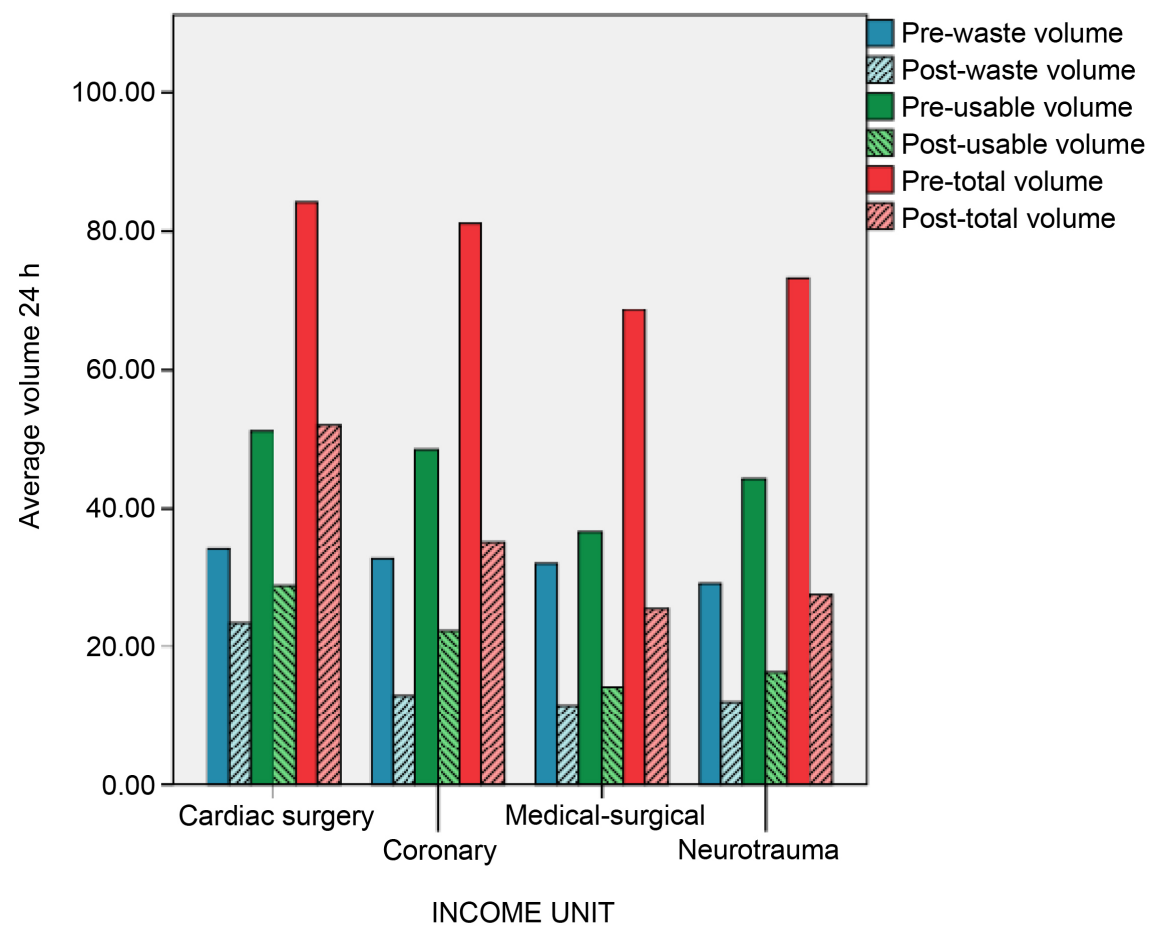

Figure 3. The alverage volume of waste, average volume of usable and total average volume in $24 \mathrm{~h}$, acording ICU units.

\subsection{Results of the Correlation of $\mathrm{Hb}$ and the Sex, Balance, Severity Index and Collected Blood Volume Variables}

No significant statistical differences were found between the haemoglobin variable 
Table 2. Number of analyses according to pathology causing admission. Heartfailure included Acute myocardialinfarction (AMI) and cardiorespiratory arrest (CRA). Subarachnoid haemorrhage (SAH), acute respiratory failure (ARF), post abdominal surgery Post. Abd). ${ }^{*} \mathrm{p}<0.05$.

\begin{tabular}{|c|c|c|c|c|c|c|c|c|c|c|c|}
\hline \multirow[t]{2}{*}{ Unit } & \multirow[t]{2}{*}{ Diagnosis } & \multicolumn{2}{|c|}{$\mathrm{N}$} & \multicolumn{2}{|c|}{$\begin{array}{l}\text { Number of } \\
\text { samples } \bar{X}\end{array}$} & \multicolumn{2}{|c|}{$\begin{array}{c}\text { Volume of } \\
\text { waste } \bar{X}(\mathrm{~mL})\end{array}$} & \multicolumn{2}{|c|}{$\begin{array}{l}\text { Volume of usable } \\
\text { blood } \bar{X}(\mathrm{~mL})\end{array}$} & \multicolumn{2}{|c|}{$\begin{array}{c}\text { Total average volum } \bar{X} \\
(\mathrm{~mL})(\mathrm{min}-\mathrm{max})\end{array}$} \\
\hline & & Pre & Post & Pre & Post & Pre & Post & Pre & Post & Pre & Post \\
\hline \multirow{2}{*}{ Coronary Unit } & AMI & 42 & 16 & $\begin{array}{c}7.5 \\
( \pm 1.9)\end{array}$ & $\begin{array}{c}6 \\
( \pm 1.8)\end{array}$ & $\begin{array}{l}31.83 \\
( \pm 11.7)\end{array}$ & $\begin{array}{c}15.3 \\
( \pm 10.9)\end{array}$ & $\begin{array}{c}49.02 \\
( \pm 15.8)\end{array}$ & $\begin{array}{c}23.7 \\
( \pm 8.6)\end{array}$ & $\begin{array}{c}80.85 \\
(42.7-141)\end{array}$ & $\begin{array}{c}39.1 \\
(22.1-68.10)\end{array}$ \\
\hline & CRA & 7 & 13 & $\begin{array}{l}8.2 \\
( \pm 2)\end{array}$ & $\begin{array}{c}7.5 \\
( \pm 1.5)\end{array}$ & $\begin{array}{c}37.37 \\
( \pm 13.3)\end{array}$ & $\begin{array}{c}14.1 \\
( \pm 6.8)\end{array}$ & $\begin{array}{l}53.82 \\
( \pm 23.7)\end{array}$ & $\begin{array}{c}24.8 \\
( \pm 12.9)\end{array}$ & $\begin{array}{c}91.19 \\
(39.5-135.9)\end{array}$ & $\begin{array}{c}39 \\
(20.8-83.6)\end{array}$ \\
\hline \multirow{3}{*}{$\begin{array}{c}\text { Medical Surgery } \\
\text { Unit }\end{array}$} & ARF & 10 & 6 & $\begin{array}{c}7 \\
( \pm 1.8)\end{array}$ & $\begin{array}{c}3.8 \\
( \pm 1.1)\end{array}$ & $\begin{array}{l}25.71 \\
( \pm 12)\end{array}$ & $\begin{array}{c}6.5 \\
( \pm 3.1)\end{array}$ & $\begin{array}{c}40.30 \\
( \pm 14.3)\end{array}$ & $\begin{array}{c}20.5 \\
( \pm 17.9)\end{array}$ & $\begin{array}{c}66.01 \\
(35.9-103.9)\end{array}$ & $\begin{array}{c}27 \\
(8-52.6)\end{array}$ \\
\hline & Post.Abd & 5 & 5 & $\begin{array}{c}5.5 \\
( \pm 1.5)\end{array}$ & $\begin{array}{c}3.6 \\
( \pm 1.3)\end{array}$ & $\begin{array}{c}25.2 \\
( \pm 11.4)\end{array}$ & $\begin{array}{c}6.6 \\
( \pm 4)\end{array}$ & $\begin{array}{c}43.9 \\
( \pm 8.79)\end{array}$ & $\begin{array}{c}14.3 \\
( \pm 2.2)\end{array}$ & $\begin{array}{c}52.9 \\
(52.9-104.9)\end{array}$ & $\begin{array}{c}20.9 \\
(13.6-27.1)\end{array}$ \\
\hline & Septic & 5 & 4 & $\begin{array}{c}7.2 \\
( \pm 1.8)\end{array}$ & $\begin{array}{c}6 \\
( \pm 1.6)\end{array}$ & $\begin{array}{c}23.25 \\
( \pm 11.6)\end{array}$ & $\begin{array}{c}19.2 \\
( \pm 4.9)\end{array}$ & $\begin{array}{c}38.15 \\
( \pm 11.2)\end{array}$ & $\begin{array}{c}26.1 \\
( \pm 14.1)\end{array}$ & $\begin{array}{c}61.4 \\
(526.9-85.9)\end{array}$ & $\begin{array}{c}45 \\
(31.8-57.6)\end{array}$ \\
\hline HeartSurgery Unit & By-pass/Valv & 16 & 42 & $\begin{array}{c}7.8 \\
( \pm 0.8)\end{array}$ & $\begin{array}{c}6.5 \\
( \pm 1.7)\end{array}$ & $\begin{array}{l}39.26 \\
( \pm 1.4)\end{array}$ & $\begin{array}{c}21.2 \\
( \pm 14.1)\end{array}$ & $\begin{array}{l}52.78 \\
( \pm 1.4)\end{array}$ & $\begin{array}{c}27.4 \\
( \pm 6.6)\end{array}$ & $\begin{array}{c}92.04 \\
(48.2-120.6)\end{array}$ & $\begin{array}{c}48.5 \\
(15.1-96.9)\end{array}$ \\
\hline \multirow{2}{*}{ Neurocritical Unit } & CT & 7 & 7 & $\begin{array}{c}5.6 \\
( \pm 1.7)\end{array}$ & $\begin{array}{c}4.5 \\
( \pm 1.7)\end{array}$ & $\begin{array}{c}26 \\
( \pm 11.8)\end{array}$ & $\begin{array}{c}14.5 \\
( \pm 5.1)\end{array}$ & $\begin{array}{c}28.78 \\
( \pm 21.3)\end{array}$ & $\begin{array}{l}14.4 \\
( \pm 8)\end{array}$ & $\begin{array}{c}54.78 \\
(18.7-64.9)\end{array}$ & $\begin{array}{c}29 \\
(16.5-44.8)\end{array}$ \\
\hline & SAH & 6 & 19 & $\begin{array}{c}5.3 \\
( \pm 2)\end{array}$ & $\begin{array}{c}4.7 \\
( \pm 1.5)\end{array}$ & $\begin{array}{c}29.95 \\
( \pm 14.1)\end{array}$ & $\begin{array}{c}10.5 \\
( \pm 4.9)\end{array}$ & $\begin{array}{c}28.56 \\
( \pm 15.1)\end{array}$ & $\begin{array}{c}16.7 \\
( \pm 10.9)\end{array}$ & $\begin{array}{c}28.56 \\
(37.4-120.6)\end{array}$ & $\begin{array}{c}26.5 \\
(10-60.9)\end{array}$ \\
\hline $\mathrm{p}$ & & & & \multicolumn{2}{|c|}{$\mathrm{p}<0.001^{*}$} & \multicolumn{2}{|c|}{$\mathrm{p}<0.001^{*}$} & \multicolumn{2}{|c|}{$\mathrm{p}<0.001^{*}$} & \multicolumn{2}{|c|}{$\mathrm{p}<0.001^{*}$} \\
\hline
\end{tabular}

and the sex, severity index and collected blood volume variables. There is a small negative correlation between the $\mathrm{Hb}$ at 24 hours, the difference in haemoglobin and the ponderal balance. Greater differences in $\mathrm{Hb}$ at 24 hours were found in patients with a positive balance in comparison with those with a negative balance $(\mathrm{r}=-0.24, \mathrm{p}=0.008)$ (Figure 4$)$.

The difference in $\mathrm{Hb} 24 \mathrm{~h}$ after admission was higher in patients admitted to cardiac surgery (X: $-0.81 \mathrm{~g} / \mathrm{dL}$ ), coronary $(\mathrm{X}:-0.8 \mathrm{~g} / \mathrm{dL}$ ) and neurotrauma units (X: $-1.1 \mathrm{~g} / \mathrm{dL}$ ), this difference was only significant in postoperative cardiac surgery patients $(\mathrm{p}<0.05)$.

$38.1 \%$ of professionals used conservative techniques with zero waste for specimen collection, versus $11.6 \%$ in the pre-intervention phase. The catheters most often used for the collection of samples in the post phase were arterial cannulas and PICC, and the least used were PVC. The average waste volumes per catheter were: $3.5 \mathrm{~mL}$ of arterial cannula, $2 \mathrm{~mL}$ PVC, $2.5 \mathrm{~mL}$ PICC and $5 \mathrm{~mL} \mathrm{CVC} \mathrm{(p} \mathrm{=}$ $0.170)$

$44.9 \%$ of professionals in the post-intervention phase had between $<1$ and 1 5 years' work experience. These were the ones who discarded the most blood - 5 $\mathrm{mL}(\mathrm{p}<0.001)$ (Table 3). In the post-intervention phase, the waste volume in professionals with more experience was significantly lower than in pre-intervention phase $(\mathrm{p}<0.001)$. 


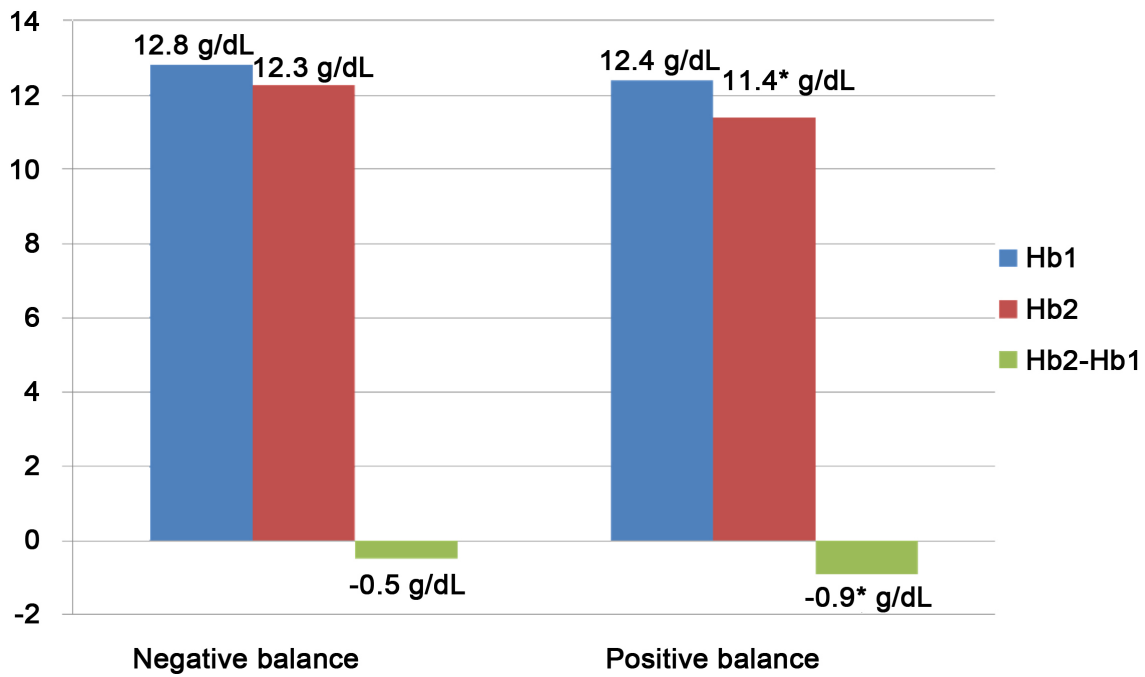

Figure 4. Correlation between haemoglobin on admission (Hb1) and at 24 hours (Hb2), and difference $\mathrm{Hb} 1-\mathrm{Hb} 2.) .{ }^{*} \mathrm{p}<0.05$.

Table 3. Wastevolumebased on professional experience. ${ }^{*}<0.001$.

\begin{tabular}{|c|c|c|c|c|c|c|c|}
\hline \multicolumn{4}{|c|}{ PRE } & \multicolumn{4}{|c|}{ POST } \\
\hline $\begin{array}{l}\text { Professional } \\
\text { experience } \\
\text { (years) }\end{array}$ & Percentage & $\begin{array}{c}\text { Wastemedian } \\
(\mathrm{mL})\end{array}$ & $\mathrm{p}$ & $\begin{array}{c}\text { Professional } \\
\text { experience } \\
\text { (years) }\end{array}$ & Percentage & $\begin{array}{c}\text { Wastemedian } \\
(\mathrm{mL})\end{array}$ & $\mathrm{p}$ \\
\hline$<1$ & $4.7 \%$ & 5.0000 & \multirow{6}{*}{$<0.001^{*}$} & $<1$ & $21.3 \%$ & 5.0000 & \multirow{6}{*}{$<0.001^{\star}$} \\
\hline $1-5$ & $16.7 \%$ & 5.0000 & & $1-5$ & $26.6 \%$ & 5.0000 & \\
\hline $6-10$ & $37.7 \%$ & 5.0000 & & $6-10$ & $17.6 \%$ & 2.0000 & \\
\hline $11-15$ & $26.7 \%$ & 5.0000 & & $11-15$ & $16.9 \%$ & 3.0000 & \\
\hline $16-20$ & $5.7 \%$ & 5.0000 & & $16-20$ & $10.8 \%$ & 0.0000 & \\
\hline$>20$ & $8.5 \%$ & 5.0000 & & $>20$ & $9.7 \%$ & 0.0000 & \\
\hline
\end{tabular}

\section{Discussion}

The blood volume collected in the post intervention phase was lower than that collected in the pre intervention phase. Promoting valuable clinical practices and benefits for patients. Some scientific societies promote initiatives recommending non-performance of certain medical or nursing practices ("Do not do"), or reduction in their frequency, such as unnecessary and repetitive laboratory tests [16] [17].

The first of the strategies implemented in this study was to reduce the number of routine tests and adjust them to the needs of each patient, which meant a $24 \%$ reduction in samples collected. Other hospital centres have designed and implemented similar interventions in hospitalised patients, obtaining a $26 \%$ reduction in laboratory tests in the post-intervention phase [18]. Sadowsky [19] et al. eliminated automated orders from the institutional programme, managing to change the pattern of analytical prescriptions which led to reducing routine tests by $15 \%-20 \%$. Eaton [11] describes three strategies consisting of education, au- 
diting and feedback on healthcare practice in relation to laboratory tests and concludes that he has obtained satisfactory results in terms of reducing the number of tests, costs, and patient and professional satisfaction. In the Coronary unit, a decrease in admissions of patients with acute myocardial infarction (AMI) was observed. Acute cardiovascular disease focused on cardiorespiratory arrest (CRA) and cardiogenic shock [20]. Although this involved more seriously ill patients, a decrease in the number of samples collected compared to the pre-intervention phase was observed, however, patients diagnosed with CRA were those who underwent more blood tests. It should be noted that the number of venous procedures in patients with uncomplicated AMI are lower than those in patients with severe cardiovascular disease (CRA, cardiogenic shock), which is why the number of tests and easy blood collection also increases in patients with more serious pathologies. Chant states that small increases in blood loss associated with phlebotomy $(3.5 \mathrm{~mL} /$ day) in critically ill patients are associated with a greater probability of blood transfusions in prolonged admissions of more than 21 days.

The second of the implemented strategies involved the use of smaller volume tubes for laboratory collections in adult patients. The usable blood volume was reduced by $50 \%$ compared to the pre-intervention phase, and the same parameters were studied. Previous studies have observed the impact of the use of paediatric tubes in adult patients, calculating rates of blood volume reduction similar to those of this study. They conclude that the amount of blood in these tubes is sufficient to obtain reliable analytical results and a significant reduction in blood volume loss [21] [22] [23]. Whitehead [15] states that the use of small volume tubes mitigates the development of anaemia, but they are insufficient to evaluate the effect on blood loss or the decrease in haemoglobin levels. Salysbury [24] relates blood loss from phlebotomy to the appearance of HAA, stressing that the use of smaller volume tubes limits the severity of anaemia. Literature is controversial regarding the claim that blood loss associated with laboratory tests significantly contributes to the development of HAA, and some studies attribute it to critically ill patients having impaired erythropoietic functions [25].

Another strategy implemented to reduce blood loss involved standardising the volume collected for blood gas analysis at $1 \mathrm{~mL}$. Jensen [14] compared the reliability of the results of blood gases with $1 \mathrm{~mL}$ and $3 \mathrm{~mL}$ syringes and concluded that they were reliable, and that the volume of blood collected was reduced by $60 \%$. We agree with Jensen [14] that it would be possible to obtain greater blood savings with this strategy by reducing the volume of blood for blood gases to 0.5 $\mathrm{mL}$.

The third strategy involved the implementation of closed systems, aimed at returning the blood waste. An increased number of professionals used conservative techniques, especially those with greater work experience. The disposal technique continued to be the most widely used, however, the average volumes decreased in the post-intervention phase in professionals with more than five years of experience. In the intervention phase, use of the zero waste technique and/or 
discarding the bare minimum was encouraged.

Arterial catheters were most often used for specimen collection in the postintervention phase, which facilitated specimen collection; unlike the pre-intervention phase, in which peripheral catheters were the most used, since there were a greater number of admissions with AMI. Low states that having artery access increases the number of blood tests and the volume of blood collected from the patient by $44 \%$, compared to patients with no arterial lines [26]. A clinical trial stated that the use of blood-saving devices has a positive impact on the patient, reducing the blood loss associated with this procedure [27]. Literature supports the use of blood-saving systems with both arterial and venous catheters, but the evidence is not sufficient to determine the impact of these devices on the decrease in haemoglobin and the need for transfusion during ICU admission.

Another option to reduce waste volumes is to standardise them according to the type of catheter. Coene [28] calculates that, by standardising the volume collected with catheters, the daily blood collected per patient decreases by $25 \%$. Whitehead compares the use of closed and conventional systems for blood collection, concluding that using blood-saving devices can reduce volume loss by $25 \%$.

With regard to haemoglobin, it has been described that the mean haemoglobin level of the critically ill patient upon admission to the ICU is approximately $11 \mathrm{~g} / \mathrm{dl}$, with a prevalence of anaemia of $65 \%$ [29] [30]. In our study, the average $\mathrm{Hb}$ at admission was $12 \mathrm{~g} / \mathrm{dl}$. The strategies implemented have been effective in reducing blood volumes related to phlebotomy, but they have not been sufficient to prevent the appearance of iatrogenic anaemia or to relate it to the decrease in haemoglobin. This issue is controversial, and Makam [31] states that it is unlikely that blood loss due to phlebotomy is the main cause of HAA. Institutional support and interdisciplinary collaboration are required to disseminate, implement, evaluate and provide feedback on "care bundles" to reduce the appearance of iatrogenic anaemia [32].

\section{Limitations}

The study was carried out in two phases, the control group being different to the post-intervention group, which may condition the variability in the decrease in haemoglobin at 24 hours. The data collection period was only 24 hours, and in future studies long-term data should be collected to be able to establish possible causes associated with the decrease in haemoglobin. The costs of these strategies have not been evaluated. In future studies it would be interesting to measure the saving costs after the implementation of the strategies.

\section{Conclusions}

In summary, individualising the analytical needs of the patients made it possible to reduce the number of blood samples collected. Greater effort should be invested in limiting analytical testing and eliminating routine orders to improve 
the results of this strategy.

The use of smaller volume tubes and the standardisation of filling blood gas syringes have reduced the usable blood volume collected from critically ill patients by $50 \%$ in the first 24 hours of admission.

There has been an increase in the use of conservative techniques to enable nurses to obtain samples. Using blood-conserving devices to collect blood samples with a catheter would reduce the clinical variability of the technique and the volume of blood waste.

All strategies implemented reduced the phlebotomy blood volume to a greater or lesser extent, especially the use of smaller volume tubes. The other strategies have room for improvement. In future research, professionals involved should be made aware of the importance of minimising blood loss secondary to routine collections to mitigate AAI as much as possible.

\section{Acknowledgements}

We send our thanks to all our colleagues from ICU HUSE for the collaboration and participation in the collection of data, and to Aina Millán Pons for your support in statistical analysis.

\section{Conflicts of Interest}

The authors declare that there is no conflict of interest.

\section{The Institution at Which the Work Was Performed}

Son Espases University Hospital, Spain.

\section{References}

[1] Corwin, H.L. (2004) Anemia and Blood Transfusion in the Critically Ill Patient: Role of Erythropoietin. Critical Care, 8, Article No. S42. https://doi.org/10.1186/cc2411

[2] Vincent, J.L., Baron, J.F., Reinhart, K., Gattinoni, L., Thijs, L., Webb, A., et al. (2002) Anemia and Blood Transfusion in Critically Ill Patients. JAMA, 288, 1499-1507. https://doi.org/10.1001/jama.288.12.1499

[3] Vinagre Gaspar, R., Cornejo Bauer, C., Murillo Pérez, A., Molano Alvarez, E., Muñoz López, O., Morales Sánchez, C., et al. (2010) Pérdidas sanguíneas diagnósticas en pacientes con trauma grave. Enfermería Intensiva, 21, 120-125. https://doi.org/10.1016/j.enfi.2010.04.001

[4] Chant, C., Wilson, G. and Friedrich, J.O. (2006) Anemia, Transfusion, and Phlebotomy Practices in Critically Ill Patients with Prolonged ICU Length of Stay: A Cohort Study. Critical Care, 10, Article No. R140. https://doi.org/10.1186/cc5054

[5] James, T., Barty, R., Liu, Y., Rochwerg, B., Heddle, N. and Siegal, D.M. (2018) Blood Loss Due to Laboratory Testing in Critical Care Patients: A Retrospective Cohort Study. Blood, 132, Article No. 4885. https://doi.org/10.1182/blood-2018-99-114289

[6] Barie, P.S. (2004) Phlebotomy in the Intensive Care Unit: Strategies for Blood Conservation. Critical Care, 8, Article No. S34. https://doi.org/10.1186/cc2454

[7] Maqueda-Palau, M. and Pérez-Juan, E. (2018) Blood Volume Extracted from the 
Critical Patient in the First 24 Hours after Admission. Volumen de sangre extraído al paciente crítico las primeras $24 \mathrm{~h}$ de ingreso. Enfermería Intensiva, 29, 14-20. https://doi.org/10.1016/j.enfi.2017.09.002

[8] Pérez Juan, E. and Maqueda Palau, M. (2018) Flebotomía en la unidad de cuidados intensivos: volumen útil vs. volumen desechado. Evidentia, 15, 1-6.

http://ciberindex.com/c/ev/e11719

[9] World Health Assembly, 63. (2010) Availability, Safety and Quality of Blood Products. World Health Organization. http://apps.who.int/gb/ebwha/pdf_files/WHA63/A63_R12-en.pdf

[10] Althoff, F.C., Neb, H., Herrmann, E., Trentino, K.M., Vernich, L., Füllenbach, C. Freedman, J., Waters, J.H., et al. (2019) Multimodal Patient Blood Management Program Based on a Three-Pillar Strategy: A Systematic Review and Meta-Analysis. Annals of Surgery, 269, 794-804. https://doi.org/10.1097/SLA.0000000000003095

[11] Eaton, K.P., Levy, K., Soong, C., Pahwa, A.K., Petrilli, C., Ziemba, J.B., Cho, H.J., Alban, R., Blanck, J.F. and Parsons, A.S. (2017) Evidence-Based Guidelines to Eliminate Repetitive Laboratory Testing. JAMA Internal Medicine, 177, 1833-1839. https://doi.org/10.1001/jamainternmed.2017.5152

[12] Badamosi, R., DiGiovine, B., Iribarren, J. and McClellan, B. (2011) Impact of Blood Conservation Strategy in the Medical Intensive Care Unit (The Anemia Bundle). Chest, 140, Article No. 347A. https://doi.org/10.1378/chest.1116780

[13] Dale, J.C. and Pruett, S.K. (1993) Phlebotomy-A Minimalist Approach. Mayo Clinic Proceedings, 68, 249-255. https://doi.org/10.1016/S0025-6196(12)60044-5

[14] Jensen, P.R. and Markewitz, B.A. (2016) Safe Reduction of Blood Volume in the Blood Gas Laboratory. Laboratory Medicine, 47, 326-329. https://doi.org/10.1093/labmed/lmw039

[15] Whitehead, N.S., Williams, L.O., Meleth, S., Kennedy, S.M., Ubaka-Blackmoore, N., Geaghan, S.M., Nichols, J.H., et al. (2019) Interventions to Prevent Iatrogenic Anemia: A Laboratory Medicine Best Practices Systematic Review. Critical Care, 23, Article No. 278. https://doi.org/10.1186/s13054-019-2511-9

[16] Bulger, J., Nickel, W., Messler, J., Goldstein, J., O’Callaghan, J., Auron, M., et al. (2013) Choosing Wisely in Adult Hospital Medicine: Five Opportunities for Improved Healthcare Value. Journal of Hospital Medicine, 8, 486-492. https://doi.org/10.1002/jhm.2063

[17] González de Molina, F., Gordo, F., Estella, A., Morrondo, P., Fernández, J., Caballero, J., et al. (2018) "Do Not Do" Recommendations of the Working Groups of the Spanish Society of Intensive and Critical Care Medicine and Coronary Units (SEMICYUC) for the Management of Critically Ill Patients. Medicina Intensiva (English Edition), 42, 425-443. https://doi.org/10.1016/j.medine.2018.04.007

[18] Dhanani, J.A., Barnett, A.G., Lipman, J. and Reade, M.C. (2018) Strategies to Reduce Inappropriate Laboratory Blood Test Orders in Intensive Care Are Effective and Safe: A Before-and-After Quality Improvement Study. Anaesthesia and Intensive Care, 46, 313-320. https://doi.org/10.1177\%2F0310057X1804600309

[19] Sadowski, B.W., Lane, A.B., Wood, S.M., Robinson, S.L. and Kim, C.H. (2017) High-Value, Cost-Conscious Care: Iterative Systems-Based Interventions to Reduce Unnecessary Laboratory Testing. American Journal of Medicine, 130, 1112.e1-1112.e7. https://doi.org/10.1016/j.amjmed.2017.02.029

[20] Garcías, M., March, C., Janer, T., Soliva, L., Figueras, A., García, I., et al. (2019) Retrato actual de la Unidad Coronaria. Presentado en el LIV Congreso Nacional de la Sociedad Española de Medicina Intensiva, Crítica y Unidades Coronarias 
(SEMICYUC), Palma Mallorca, 9-12 June 219, 1-3.

[21] Kurniali, P.C., Curry, S., Brennan, K.W., Velletri, K., Shaik, M., Schwartz, K.A., et al. (2014) A Retrospective Study Investigating the Incidence and Predisposing Factors of Hospital-Acquired Anemia. Anemia, 2014, Article ID: 634582. https://doi.org/10.1155/2014/634582

[22] Dolman, H.S., Evans, K., Zimmerman, L.H., Lavery, T., Baylor, A.E., Wilson, R.F., et al. (2015) Impact of Minimizing Diagnostic Blood Loss in the Critically Ill. Surgery, 158, 1083-1088. https://doi.org/10.1016/j.surg.2015.05.018

[23] Sanchez-Giron, F. and Alvarez-Mora, F. (2008) Reduction of Blood Loss from Laboratory Testing in Hospitalized Adult Patients Using Small-Volume (Pediatric) Tubes. Archives of Pathology \& Laboratory Medicine, 132, 1916-1919. https://doi.org/10.5858/132.12.1916

[24] Salisbury, A.C., Reid, K.J., Alexander, K.P., Masoudi, F.A., Lai, S.M., Chan, P.S., Bach, R.G., et al. (2011) Diagnostic Blood Loss from Phlebotomy and Hospital-Acquired Anemia during Acute Myocardial Infarction. Archives of Internal Medicine, 171, 1646-1653. https://doi.org/10.1001/archinternmed.2011.361

[25] Van der Bom, J.G. and Cannegieter, S.C. (2015) Hospital-Acquired Anemia: The Contribution of Diagnostic Blood Loss. Journal of Thrombosis and Haemostasis, 13, 1157-1159. https://doi.org/10.1111/jth.12886

[26] Low, L.L., Harrington, G.R. and Stoltzfus, D.P. (1995) The Effect of Arterial Lines on Blood-Drawing Practices and Costs in Intensive Care Units. Chest, 108, 216-219. https://doi.org/10.1378/chest.108.1.216

[27] MacIsaac, C.M., Presneill, J.J., Boyce, C.A., Byron, K.L. and Cade, J.F. (2003) The Influence of a Blood Conserving Device on Anaemia in Intensive Care Patients. Anaesth Intensive Care, 31, 653-657. https://doi.org/10.1177\%2F0310057X0303100607

[28] Coene, K.L., Roos, A.N. and Scharnhorst, V. (2015) Iatrogenic Anemia/Twenty-Five Million Liters of Blood into the Sewer: Comment. Journal of Thrombosis and Haemostasis, 13, 1160-1161. https://doi.org/10.1111/jth.12831

[29] Walsh, T.S., Lee, R.J., Maciver, C.R., Garrioch, M., MacKirdy, F., Binning, A.R., et al. (2006) Anemia during and at Discharge from Intensive Care: The Impact of Restrictive Blood Transfusion Practice. Intensive Care Medicine, 32, 100-109. https://doi.org/10.1007/s00134-005-2855-2

[30] Muñoz, M., Noval, L., García, J.A. and Naveira, E. (2007) Prevalencia y tratamiento de la anemiaen el paciente crítico. Medicina Intensiva, 31, 388-398. https://doi.org/10.1016/S0210-5691(07)74843-X

[31] Makam, A.N., Nguyen, O.K., Clark, C. and Halm, E.A. (2017) Incidence, Predictors, and Outcomes of Hospital-Acquired Anemia. Journal of Hospital Medicine, 12, 317322. https://doi.org/10.12788/jhm.2723

[32] Rivera, D. and Pérez, A. (2011) Blood-Saving Techniques in Surgery. Colombian Journal of Anestesiology, 39, 545-559. https://doi.org/10.5554/rca.v39i4.148

http://www.scielo.org.co/scielo.php?script=sci_arttext\&pid=S0120-33472011000400 007\&lng=en 